\title{
INTERACTIVE ANIMATION BASED LEARNING MEDIA ON STARTER SYSTEM MATERIALS FOR VOCATIONAL STUDENTS
}

\author{
Arif Priambodo and Zainal Arifin \\ Universitas Negeri Yogyakarta, Indonesia \\ E-mail: ambodo13@gmail.com
}

\begin{abstract}
This study aimed at (1) developing interactive animated learning media on starter system materials for the subject of light electrical vehicle maintenance, (2) examining the effectiveness of developed media assessed from the aspects of display, program, and interactive based on students' responses. The research model used was the development model of Analysis, Design, Development, Implementation, and Evaluation (ADDIE) developed by Branch. This study was conducted at SMK PGRI 4 Ngawi. Instruments used to obtain data were interviews and questionnaires. Product development was validated by material experts and media experts, then was tested in small (limited) and large trials (field). The results of this development study were as follows: (1) The analysis result of developed media showed that the media is feasible to be used in learning or in a good category. (2) The results of the assessment showed that the aspects of display, program and interactivity were all in the good category.
\end{abstract}

Keywords: animation, interactive, learning media, starter system

\section{INTRODUCTION}

Education has an important role in the development of the quality of human resources. $21^{\text {st }}$ century education is a challenge for teachers as educators, and vocational secondary schools as educational institutions that produce graduates who are ready to work. The $21^{\text {st }}$ century skills curriculum is useful for students and teachers to prepare for future careers, where creativity and skills in using technology are the key to success [1]. The concept of $21^{\text {st }}$ century education becomes a learning challenge for teachers as educators, and schools for the place of learning organizers that education can be integrated with the development of technology and communication. The students are required to have skills, knowledge, and the ability in the technology, media, and information field, learning skills, innovation as well as life and career's skills [2].

Learning is considered to be a system which contains an interrelated and continuous component that aims to achieve a defined goal. Learning components include objectives, materials, methods, media, and evaluation [3]. Learning methods that have been used in the classroom still need to be refined. Teaching methods that teachers often use is a lecture method. This lecture method can be combined with the use of learning media that utilizes computer technology. One of the efforts to improve the quality of learning is by presenting innovative learning materials, and attract students to learn through the media pursuit.

The use of instructional media is very important in the learning process. Learning media that teachers often use in learning activities is the conventional learning media (blackboard). The use of learning media can improve students' understanding of the subject matter and able to improve students' learning motivation. The use of media in the learning process aims for the learning process can take place effectively and efficient so that the quality of education can be improved [4]. Students will learn more and better understand the lessons through visual aids 
such as pictures, videos and movies [5]. This proves that the media-based learning technology and communication is very good if used in the media learning in the classroom. There was a significant difference between students using the developed instructional media and those who did not [6].

One form of application that can be used in learning is multimedia [7]. The advantages of interactive multimedia programs related to interactivity elements that provide opportunities for learners to respond, and perform various activities that eventually can also be responded back by a multimedia program with a feedback [8]. Multimedia forces users to interact with the material. This interaction varies as the user is able to select the material to be learned, move the desired page, or can input the answer from the exercise then the computer responds by giving the results of the work and discussion through feedback. The interactive learning media contributes a positive effect in improving students' learning outcomes [9][13]. It improves students' learning motivation [14] and motivation shows considerably beneficial impacts on learning results [15].It encourages innovations in education as solutions to conventional teaching and learning methodologies in the classroom [16]. The interactive media foster better learning achievement than the power point media does [17].

Media to be developed is an interactive learning media based on animation. An interactive learning media based on animation contains material about understanding and explanation about Starter System that is made interactive so that students can choose sub material that want to be studied, and students are free to choose the desired menu option. The material is packed as interesting as it is, and is displayed in the form of text, images, and animations. The use of multimedia in learning proves to be a feasible and viable alternative to traditional classroom [18].

Animation can promote learner understanding when used in ways that are consistent with the cognitive theory of multimedia learning [19]. The student's response in animation learning media is very positive [20]. It aims to make students easy and motivated to learn about Starter System materials. Interactive learning media based on animation by utilizing technology is expected to improve students' understanding and motivation in the subject of Light Electric Vehicle Maintenance, especially in the materials of Starter System.

Some studies explain the influence of the use of learning media, among others: Oyedele et al. [21] explained that to improve the learning process, there is a need to use learning and technology media with the aim of increasing student learning interest. All levels of education must be able to utilize the media, both modern media and traditional media. Omodara \& Adu [21] explained that media education and multimedia technology have a positive impact on the teaching and learning process [22]. Based on the research described above, it can be concluded that animation-based learning media has a positive impact. The results of each study can be categorized as feasible, valid, and good to be used as learning media in schools. Interactive animation-based learning media especially multimedia can provide benefits to teachers and students in learning activities in vocational schools. Therefore the objective of this study was to develop interactive animated learning media for vocational students. 


\section{METHOD}

This study is categorized as research and development ( $\mathrm{R} \& \mathrm{D})$. The development method used the Analysis, Design, Development, Implementation, and Evaluation (ADDIE) development model by Branch [23]. The development that will be done by the researcher is development of interactive learning media based on animation on starter system materials for vocational students.

The subject of this study was a vocational high school in Ngawi city namely SMK PGRI 4 Ngawi. The analysis phase aims to find the data in SMK PGRI 4 Ngawi which became the place of research. In the analysis phase there were five stages of analysis, that were: validate the data in the school, determine the intentional objectives, confirm and identify the necessary resources, and prepare the project management plan.

At the design stage, research instrument, flowchart, and storyboard of the media design were prepared. In the development stage, media production, and product validation were developed. This validation included instrument validation, material validation and media validation.

At the implementation stage, learning media was implemented in the learning process. In the implementation stage, the product was tested in an experiment class. There were two kinds of product trials, namely a small group trial (limited), and a large group trial (field).

The evaluation was the stage of evaluating the data obtained from the analysis and evaluation tests that have been given in the previous stages. Techniques and instruments used were questionnaires, interviews, and observation. Questionnaire used were questionnaires for material experts, questionnaires for media experts, questionnaires for students, and questionnaires for subject teachers. Learning media developed was tested to the students to examine the effectiveness of the product.

The analytical technique was obtained from validation analysis done by internal reviewer (lecturers of media expert and lecturers of material expert) and external reviewer (teachers of light electric vehicle maintenance) and students. Analysis techniques for instruments validation used calculations with Aiken's $\mathrm{V}$ with the following equation [24].

$$
\mathrm{V}=\sum \mathrm{s} /[\mathrm{n}(\mathrm{c}-1)]
$$

Then the value of Aiken's V was compared with the following quality categories [25] presented in Table 1.

Table 1. Category of Aiken's V

\begin{tabular}{ccc}
\hline No & Range & Quality Category \\
\hline 1 & $0.8<V \leq 1$ & Very Good \\
2 & $0.6<V \leq 0.8$ & Good \\
3 & $0.4<V \leq 0.6$ & Acceptable \\
4 & $0.2<V \leq 0.4$ & Poor \\
\hline
\end{tabular}

Feasibility analysis media was calculated by comparing the average score with quality criteria the following quality criteria presented in Table 2 [26].

Table 2. Media Quality Classification

\begin{tabular}{cc}
\hline Formula & Classification \\
\hline$X>X_{\text {average }}+1.8 \times s b_{i}$ & Very Good \\
$X_{\text {average }}+0.6 \times s b_{i}<X \leq$ & Good \\
$X_{\text {average }}+1.8 \times s b_{i}$ & \\
$X_{\text {average }}-0.6 \times s b_{i}<X \leq$ & Acceptable \\
$X_{\text {average }}+0.6 \times s b_{i}$ & \\
$X_{\text {average }}-1.8 \times s b_{i}<X \leq$ & Poor \\
$X_{\text {average }}-0.6 \times s b_{i}$ & \\
$X \leq X_{\text {average }}-1.8 \times s b_{i}$ & Very Poor \\
\hline
\end{tabular}

\section{RESULTS AND DISCUSSION}

The components in interactive learning media based on animation include: (1) Initial 
display which contains title, welcome, developer name, UNY logo, and start button to start Starter System app., (2) The main menu which contains several options including: profile, destination, introduction, starter type, examination, and evaluation. In addition there is a button information icon, volume, and exit the application, (3) The destination menu containing competency standards, basic competencies, and indicators, (4) Introduction menu containing description, basic principles, starter type, and characteristics. At the introduction stage is a general material about the starter system. The home button serves to return to the main menu, (5) The starter type menu, containing conventional type starter system materials, starter reduction, and a starter system simulation, (6) Inspection menu containing the demolition, inspection, assembly, and check system, (7) Evaluation menu containing examples of questions then at the end of the sample questions and answers, discussion, and repeat. At the end of the work will be known score of the workmanship, and (8) The profile menu containing the developer profile and the mentor profile.

The results of the product assessment from several experts showed that the instruments used for retrieval were valid research data. The result of the analysis of expert assessment result revealed that the average of $\mathrm{V}$ Aiken index was $\mathrm{s}$ 0.81.The result of the materials aspect based on expert validation result showed that the average of $\mathrm{V}$ Aiken index was in the range of 0.37 to 1.00 i.e. 0.83 . Based on the average Aiken V, the starter system materials used in animated interactive learning media for vocational students were considered to be valid.

Based on the assessment of media experts, the developed interactive learning media was considered to be valid with the assessment results from the aspect of display scored 81 and 3.38 with a good category. The assessment of media experts indicated that the developed interactive learning media was considered to be valid with the assessment results of the program operation aspect scored 18 and the average score was 3 with a good category. Based on the assessment of media experts, the developed interactive learning media was considered to be valid with the total score of navigation assessment of 20 and the average score of 3.33 with a good category. The total score of the aspect of the benefit was 42 and the average score was 3.5 with a very good category.

Based on the assessment from media experts, the developed interactive learning media was considered to be valid with the assessment results of all aspects of the assessment scored 161. The average score was 3.3 with good feasibility category, and the feasibility percentage was $83.85 \%$.

The results from small (limited) group trials stated as excellent. The results of small group trial calculation of the average final scored 3.46 categorized as very good, and the percentage of feasibility was $86.5 \%$. Furthermore, the results from large group trials (field) showed that the average final score of all aspects was 3.19 which was in the range of scores more than 117.6 to 142.8 or mean final score more than 2.80 to 3.40 with a good product category. In addition, the percentage of media learning eligibility was $79.86 \%$.

The feasibility outcome of the overall assessment calculation on validation testing by materials and media validators in small or limited group trials and large group trial or field trials showed that the final score was 3.36 with a good feasibility category. The scores from the expert media validation was converted to range 1 to 5 . Conversion results from validation scores from media aspect can be seen in Table 3 . The results of product 
validation assessment by media validator of each aspect can be seen in Table 4 .

Table 3. Convertion of Validation Scores

\begin{tabular}{ccc}
\hline Score Range & $\begin{array}{c}\text { Average } \\
\text { Score }\end{array}$ & Category \\
\hline $\mathrm{X} \geq 81.6$ & $>3.4$ & Very Good \\
$67.2<\mathrm{X}<81.6$ & $>2.8$ to 3.4 & Good \\
$52.8<\mathrm{X}<67.2$ & $>2.2$ to 2.8 & Acceptable \\
$38.4<\mathrm{X}<52.8$ & $>1.6$ to 2.2 & Poor \\
$\mathrm{X} \leq 38.4$ & $\leq 1.6$ & Very Poor \\
\hline
\end{tabular}

Table 4. Media Validation Results of Each Aspect

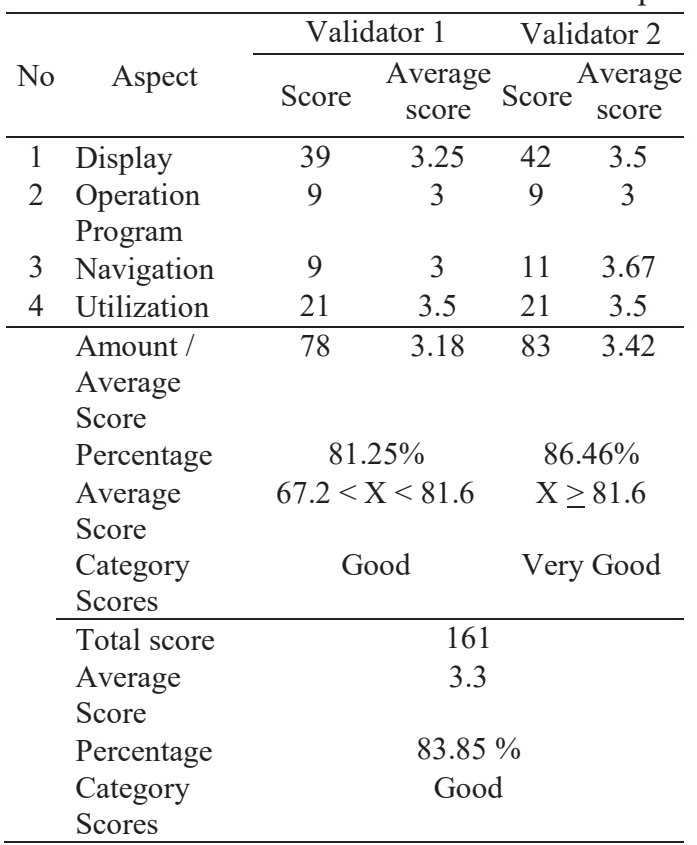

The small or limited group trials were conducted on 9 students. The results revealed that the scores for display, program, and interactivity were 438 with the final score of $3.48,431$ with the final score of 3.42 and 439 with the final score of 3.48 which were all classified as very good. Figure 1 presents the scores of the small scale of small group trials.

The results of field trials showed that the aspects of program, display, interactivity obtained the average score of $3.21,3.13$ and 3.19 with the average final score of the three aspects was 3.19 categorized as good. The results of this calculation of each aspect in the field trial can be seen in Figure 2.

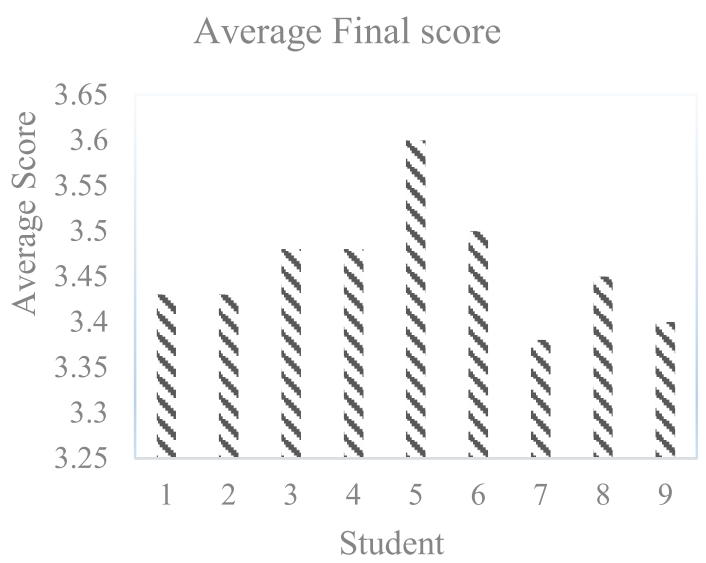

Figure 1. The Scores of the Small Scale Trial

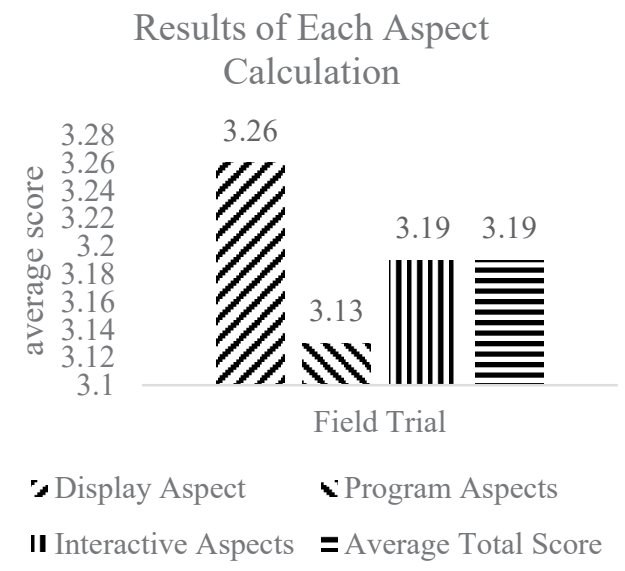

Figure 2. Field Trial Results

The feasibility test results of the developed learning media was obtained from the total score of all of assessment that consisted of product validation by materials and media validators, small or limited group trial conducted by 9 students and large or field group trial conducted by 55 students.

The results of the product assessment at the validation stage achieved the average score of 3.50 categorized as very good. While the assessment of media experts, small group trials and field trials showed the average scores of 3.30 with a good category, 3.46 with a very good category, and 3.19 with 
a good category respectively. The results of feasibility testing can be seen in Figure 3. The calculation of the overall assessment obtained a final score of 3.36 with the category of good. Based on these results, the developed learning media was considered feasible to be used as a medium of learning in teaching and learning process.

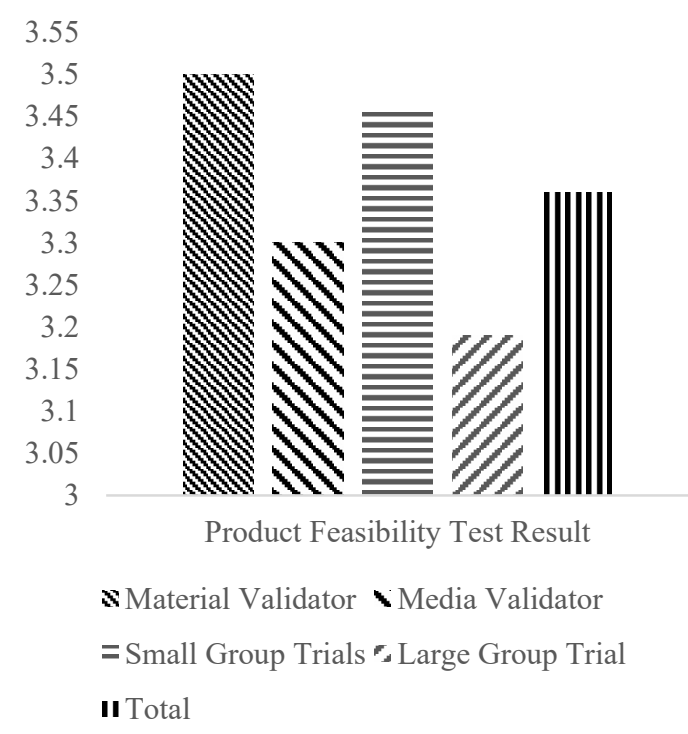

Figure 3. Results of Media Feasibility Test Based on Animation Starter System

\section{CONCLUSION}

The product of animation-based learning media on starter system materials for vocational school students is concluded to be feasible to be used as learning media in teaching and learning process. This was based on the assessment results on by materials and media validators, small or limited group trial and large group trial or field trial. It is obtained the final score of 3.36 classified as having good feasibility. The scores of the effectiveness assessment based on the students' responses for the aspect of display, program and interactivity were 3.13 ; 3.26 and 3.19 respectively. All aspects were classified in the good category. The final score was 3.19 which was in the score range of more than 117.6 to 142.8 or the mean final score more than 2.80 to 3.40 categorized as good product. The percentage of media learning eligibility is $79.86 \%$ which means the media is effective to be used in teaching learning process.

\section{REFERENCES}

[1] H. A. Alismail and P. McGuire, "21st Century Standards and Curriculum: Current Research and Practice," $J$. Educ. Pract., vol. 6, no. 6, pp. 150 154, 2015.

[2] B. Trilling and C. Fadel, 21st Century Skills: Learning for life in Our Times. San Francisco: Jossey-Bass A Wiley Imprint, 2009.

[3] R. Susilana and Riyana, Media Pembelajaran. Bandung: $\mathrm{CV}$. Wacana Prima, 2007.

[4] J. D. Latuheru, Media Pembelajaran dalam Proses Belajar-Mengajar Masa Kini. Jakarta: Indonesian Department of Education and Culture, 1988.

[5] I. M. Listiyani and A. Widayati, "Pengembangan Komik sebagai Medai Pembelajaran Akuntansi pada Kompetensi Dasar Persamaan Dasar Akuntansi untuk Siswa SMA kelas XI," J. Pendidik. Akunt. Indones., vol. 10, no. 2, Nov. 2012.

[6] S. Suyitno, I. Widianto, and S. binti Masrul, "Development of Learning Media for the Course of Two-Stroke Gasoline Motors to Improve Students' Learning Outcomes," $J$. Pendidik. Teknol. dan Kejuru., vol. 24, no. 1, pp. 83-90, Apr. 2018.

[7] Daryanto and S. Karim, Pembelajaran Abad 21. Yogyakarta: Gava Media, 2007.

[8] B. Warsita, Teknologi Pembelajaran Landasan dan Aplikasi. Jakarta: Rineka Cipta, 2008.

[9] K. R. Y. Negara, "The Effect of Animation in Multimedia ComputerBased Learning and Learning Style to the Learning Results," Turkish Online J. Distance Educ., vol. 18, no. 4, pp. 
177-190, 2017.

[10] M. Ramadhani, M. O. F. Gafari, and M. Marice, "Development of Interactive Learning Media on Material Writing Short Story Texts Based on Experience," Budapest Int. Res. Critics Linguist. Educ., vol. 2, no. 1, 2019.

[11] R. Rachmadtullah, N. Nadiroh, and M. S. Sumantri, "Development of Interactive Learning Media on Civic Education Subjects in Elementary School," in Annual Civic Education Conference, 2018.

[12] P. Yoga, K. Y. Aryawan, and P. A. K. Juniarta, "Interactive Learning Media Development with Conceptual Change for Basic Nursing Lecture I in Stikes Majapahit Singaraja," Indones. Nurs. J. Educ. Clin., vol. 1, no. 1, 2014.

[13] M. Arifin, K. Abdul Hamid, and R. Mursid, "Pengembangan Media Pembelajaran Interaktif pada Mata Pelajaran Mesin Konversi Energi Teknik Otomotif," J. Teknol. Inf. Komun. dalam Pendidik., vol. 5, no. 2, pp. 182-194, 2018.

[14] K. B. N. Noor and M. N. Aisyah, "Development of Interactive Learning Media Based On Computer to Improve Student Learning Motivation," J. Pendidik. Akuntasi Indones., vol. 16, no. 2, pp. 70-81, 2018.

[15] M. H. Lin, H. C. Chen, and K. S. Liu, "A Study of the Effects of Digital Learning on Learning Motivation and Learning Outcome," EURASIA J. Math. Sci. Technol. Educ., vol. 13, no. 7, pp. 3552-3564, 2017.

[16] F.-T. Leow and M. Neo, "Interactive Multimedia Learning: Innovating Classroom Education in a Malaysian University," Turkish Online J. Educ. Technol., vol. 13, no. 2, pp. 99-110, 2014.

[17] S. Sukoco, S. Sutiman, and M. Wakid, "Pengembangan Media Pembelajaran Interaktif Berbasis Komputer untuk
Peserta Didik Mata Pelajaran Teknik Kendaraan Ringan," J. Pendidik. Teknol. dan Kejuru., vol. 22, no. 2, pp. 215-226, Oct. 2014.

[18] B. S. P. Teoh and T. K. Neo, "Interactive Multimedia Learning: Students' Attitudes and Learning Impact in an Animation Course," Turkish Online J. Educ. Technol., vol. 6, no. 4, pp. 28-29, 2007.

[19] R. E. Mayer and R. Moreno, "Animation as an Aid to Multimedia Learning," Educ. Psychol. Rev., vol. 14, no. 1, pp. 87-99, 2002.

[20] I. M. G. Sunarya, "Pengembangan ANIME (Animation Learning Media) Berbasis Multimedia untuk Pembelajaran Dasar Sistem Komputer Bahasan Instalasi Hardware," J. Sains dan Teknol., vol. 3, no. 2, pp. 378391, 2014.

[21] O. D, Omodara and E. I, Adu, "Relevance of educational Media and Multimedia Technology for Effective Service Delivery in Teaching and Learning Processes," J. Res. Method Educ., vol. 4, no. 2, pp. 48-51, 2014.

[22] V. Oyedele, J. Rwambima, and A. Mamvuto, "Using Educational Media and Technology in Teaching and Learning Processes: A Case of Trainee Teachers at Africa University," J. Acad. Res. Int., vol. 4, no. 1, p. 292, 2013.

[23] R. M. Branch, Instructional Design: The ADDIE Approach. Boston, MA: Springer US, 2009.

[24] S. Azwar, Reliabiltas dan Validitas, 4th ed. Yogyakarta: Pustaka Pelajar, 2012.

[25] L. R. Aiken, "Three Coefficients for Analyzing the Reliability and Validity of Ratings," Educ. Psychol. Meas., vol. 45, no. 1, pp. 131-142, Mar. 1985.

[26] E. P. Widoyoko, Evaluasi Program Pembelajaran. Yogyakarta: Pustaka Pelajar, 2014. 